\title{
Pengenalan Rumput Mulato sebagai Potensi Sumber Hijauan Sapi Perah di Kelompok Peternak Tunas Mekar, KSU Tandangsari, Sumedang
}

\section{(Introduction of Mulato Grass as a Potential Source of Dairy Cattle forage at the Tunas Mekar Farmer Group, KSU Tandangsari, Sumedang)}

\author{
Novi Mayasari ${ }^{1 *}$, Lia Budimulyati Salman ${ }^{1}$, Iin Susilawati ${ }^{1}$, Apong Sandrawati ${ }^{2}$, \\ Muhammad Rifqi Ismiraj ${ }^{3}$ \\ ${ }^{1}$ Program Studi Ilmu Peternakan, Fakultas Peternakan, Universitas Padjadjaran, Jl. Raya Bandung-Sumedang Km. 21, \\ Jatinangor, Kabupaten Sumedang, Jawa Barat 45363. \\ 2 Program Studi Agroteknologi, Fakultas Pertanian, Universitas Padjadjaran, Jl. Raya Bandung-Sumedang Km. 21, \\ Jatinangor, Kabupaten Sumedang, Jawa Barat 45363. \\ ${ }^{3}$ Program Studi Peternakan, Universitas Padjadjaran PSDKU Pangandaran, Desa Cintaratu, Kecamatan Parigi, Kabupaten \\ Pangandaran, Jawa Barat 46393. \\ *Penulis Korespondensi: novi.mayasari@unpad.ac.id \\ Diterima September 2020/Disetujui April 2021
}

\begin{abstract}
ABSTRAK
Kelompok Peternak Tunas Mekar (KPTM) adalah kelompok peternak dari Koperasi Serba Usaha (KSU) Tandangsari dengan komoditas sapi perah Friesian Holstein (FH) yang memiliki tujuan usaha untuk memproduksi susu sapi dan pembibitan sapi perah. Salah satu permasalahan yang menyebabkan rendahnya produksi susu di KPTM adalah rendahnya kualitas dan ketersediaan hijauan. Oleh karena itu, perlu dicari alternatif hijauan yang memiliki keunggulan dalam biomasa serta tinggi kandungan protein dan serat, dengan harapan dapat membantu memenuhi kebutuhan nutrien ternak. Salah satu hijauan yang memiliki keunggulan dalam kandungan protein dan serat adalah rumput mulato (Brachiaria hybrid cv. Mulato) yang dilaporkan memiliki kemampuan hidup pada musim kemarau yang baik, mudah dikembangbiakkan melalui anakan, dan tingginya tingkat palatabilitas pada ternak ruminansia. Pengabdian kepada masyarakat ini bertujuan untuk mengenalkan dan menyebarluaskan potensi manfaat dari rumput mulato sebagai hijauan untuk sapi perah. Metode pengabdian masyarakat adalah kegiatan penyuluhan dan pendampingan anggota kelompok dalam pembelajaran budi daya rumput mulato. Kegiatan yang dilakukan diawali oleh tahap penjajakan, kemudian dilaksanakan tahap penyuluhan, dan dilanjutkan dengan tahap pendampingan menggunakan platform daring (grup Whatsapp). Hasil evaluasi terhadap pelaksanaan kegiatan menunjukkan adanya peningkatan pengetahuan anggota kelompok dalam budi daya rumput mulato. Hasil analisis kegiatan menunjukkan bahwa sebanyak 20 orang $(90 \%)$ peserta memahami dengan baik seluruh materi pelatihan. Indikator keberhasilan kegiatan pengabdian ini sebanyak 22 orang $(100 \%)$ peternak berhasil menanam dan membudidayakan tanaman rumput mulato. Dari kegiatan yang dilakukan, anggota KPTM mampu membudidayakan rumput mulato yang kemudian akan diperbanyak untuk memenuhi kebutuhan hijauan sapi perah.
\end{abstract}

Kata kunci: budi daya, penyuluhan, rumput mulato, sapi perah

\begin{abstract}
The Tunas Mekar Farmer Group (TMFG) is a group of farmers belong to dairy farming cooperation (KSU) Tandangsari with the commodity of Friesian Holstein (FH) dairy cattle whose business objectives are to produce cow's milk and breeding of dairy cows. One of the problems that may have caused the low milk production was the result of the low quality and availability of the forage provided by the KPTM members. It is necessary to look for forage alternatives that have advantages in biomass and protein and fiber content, in the hope that it can help meet the nutritional needs of livestock. One of the forages that has advantages in protein and fiber content is mulato grass (Brachiaria hybrid cv. Mulato) which is reported to have the ability to live in a good dry season, easy to breed through tillers, and quite high palatability by ruminants. This community service is carried out to introduce and disseminate the potential benefits of mulato grass as a potential forage source for dairy cows. Community service activities are carried out with the exploratory stage, then the extension stage, and followed by the mentoring stage using an online platform (Whatsapp group). Community service activities regarding the potential of mulato grass as a forage for dairy cows were successfully implemented. With the enthusiasm of extension participants, extension activities can increase the insight of farmers participating in the extension, reflected in the success of farmers in planting and cultivating mulato grass.
\end{abstract}

Keywords: mulato grass; dairy cow; extension; cultivation 


\section{PENDAHULUAN}

Ternak ruminansia termasuk sapi perah, secara alami memiliki kebutuhan akan pemenuhan serat (khususnya selulosa) sebagai fraksi nutrien utamanya. Hal ini disebabkan oleh adanya kompartemen rumen dalam lambungnya, yang memungkinkan adanya aktivitas mikroorganisme rumen yang bersifat selulotitik dan fibrolitik (Wang et al. 2019). Mikroorganisme rumen yang bersifat selulolitik dan fibrolitik tersebut membutuhkan selulosa sebagai sumber nutrien untuk difermentasi di dalam rumen. Hasil dari fermentasi selulosa oleh mikroorganisme rumen ini adalah asam lemak terbang (volatile fatty acids/VFA) yang menjadi sumber energi bagi ternak ruminansia (Wanapat et al. 2015). Bakteri di dalam rumen pun menjadi protein mikrobial yang bermanfaat bagi ternak. Interaksi di antara ternak ruminansia dan mikroorganisme rumen ini kita kenal sebagai simbiosis mutualisme karena keduanya saling membutuhkan.

Berdasarkan fenomena fisiologis dalam rumen tersebut, maka peran rumput sebagai penyedia fraksi nutrien serat (selulosa) dan penghasil asam asetat yang merupakan prekursor pembentuk susu sangatlah penting bagi ternak ruminansia, khususnya sapi perah. Produktivitas dan kualitas susu sapi perah ditentukan oleh kualitas hijauannya (Liu et al. 2016), termasuk rumput. Rumput merupakan salah satu faktor produksi yang terpenting untuk diperhatikan baik kualitasnya maupun keberlanjutan ketersediaannya agar produksi ternak berada dalam tingkat optimal.

Produktivitas dari peternakan sapi perah sangat dipengaruhi oleh kualitas dan kuantitas ketersediaan rumput sebagai hijauan pakan utamanya. Peternakan sapi perah milik rakyat memiliki masalah dalam kualitas dan kuantitas ketersediaan rumput, salah satunya terjadi pada Kelompok peternak Tunas Mekar (KPTM). KPTM adalah kelompok peternak dengan komoditas sapi perah Friesian Holstein (FH) yang tergabung ke dalam koperasi serba usaha (KSU) Tandangsari, Kecamatan Tanjungsari, Kabupaten Sumedang, Provinsi Jawa Barat. Kelompok ini memiliki tujuan usaha untuk memproduksi susu sapi dan bibit sapi perah. Profil KPTM disajikan pada Tabel 1.

Berdasarkan data terkait produksi susu, ratarata produksi susu harian di KPTM tergolong sedikit lebih rendah dibandingkan dengan ratarata produksi susu harian sapi perah FH di Jawa Barat, yaitu sebesar 13,9 kg/ekor/hari dengan
Tabel 1 Profil kelompok peternak sapi perah Tunas Mekar di Koperasi Serba Usaha Tandangsari, Kabupaten Sumedang.

\begin{tabular}{|c|c|}
\hline $\begin{array}{c}\text { Profil kelompok peternak } \\
\text { Tunas Mekar }\end{array}$ & Keterangan \\
\hline Jumlah anggota & 43 orang \\
\hline Jumlah ternak & 267 ekor \\
\hline Jumlah laktasi & I-VI \\
\hline $\begin{array}{ll}\text { Jumlah } & \text { ternak/petani } \\
\text { peternak } & \end{array}$ & Rata-rata 6 ekor \\
\hline Jumlah sapi laktasi & 111 ekor \\
\hline $\begin{array}{l}\text { Rata-rata produksi susu } \\
\text { harian }\end{array}$ & $12 \mathrm{~kg} /$ ekor/hari \\
\hline Luas kepemilikan lahan & $1.600 \mathrm{~m}^{2} /$ anggota \\
\hline
\end{tabular}

Sumber: Data Koperasi Serba Usaha Tandangsari (September 2020)

masa laktasi ke I-V (Makin 2012). Salah satu dari banyak faktor yang mungkin menyebabkan rendahnya produksi susu ini adalah akibat rendahnya kualitas dan ketersediaan hijauan yang diberikan oleh para anggota KPTM. Anggapan awal ini terkonfirmasi setelah dilakukannya penjajakan awal di KPTM melalui wawancara dan kuesioner, dengan hasil bahwa ransum yang biasa diberikan oleh para anggota peternak KPTM hanya berupa jerami padi dan rumput lapang (sangat jarang), Ketersediaan rumput lapang pun sangat rendah karena keterbatasan lahan. Jerami padi yang didapat pun diketahui memiliki kandungan lignin yang tinggi dan selulosa yang rendah, menyebabkan kualitasnya rendah pula.

Oleh karena rendahnya kualitas dan kuantitas hijauan yang tersedia di KPTM, maka perlu dicari alternatif hijauan yang memiliki keunggulan dalam kandungan protein dan seratnya, dengan harapan dapat membantu memenuhi kebutuhan nutrien ternak. Salah satu hijauan yang memiliki keunggulan dalam kandungan protein dan serat adalah rumput mulato (Brachiaria hybrid $\mathrm{cv}$. Mulato) yang memiliki kandungan protein kasar (PK) sebesar 10-13\% dengan kecernaan bahan kering (BK) sebesar $45-50 \%$ dan bahan organik (B0) sebesar 48-52\% (Maranatha et al. 2019). Sementara Mutimura et al. (2017) melaporkan bahwa rumput mulato pada umur tanam 60 hari memiliki kandungan BO sebesar 871 g/kg DM, kandungan protein kasar sebesar $173 \mathrm{~g} / \mathrm{kg} \mathrm{DM}$, dan kandungan neutral detergent fiber (NDF) sebesar $398 \mathrm{~g} / \mathrm{kg}$ DM. Lebih jauh lagi, Suardin et al. (2014) melaporkan bahwa rumput mulato memiliki kemampuan hidup pada musim kemarau yang baik, mudah dikembangbiakkan melalui anakan, dan palatabilitas oleh ternak ruminansia yang cukup tinggi. Selain itu, Djaya 
(2014) melaporkan bahwa rumput mulato superior dalam kualitas dan produktivitas, tahan terhadap tekanan penggembalaan, kemampuan pertumbuhan kembali (regrowth) yang baik, dapat digunakan sebagai rumput potong atau rumput gembala, palatabilitasnya sangat baik.

Menilik dari laporan-laporan penelitian tersebut, potensi rumput mulato untuk digunakan sebagai sumber hijauan cukup menjanjikan. Informasi ini dirasa perlu untuk dibagikan kepada masyarakat peternak, khususnya yang berkarya di komoditas sapi perah. Oleh karenanya, pengabdian kepada masyarakat ini dilaksanakan untuk mengenalkan dan menyebarluaskan potensi dan manfaat dari rumput mulato sebagai hijauan untuk sapi perah. Tujuan dari kegiatan pengabdian kepada masyarakat ini adalah bertambahnya wawasan para anggota peternak KPTM dalam kaitannya dengan potensi sumber hijauan mulato.

\section{METODE PELAKSANAAN KEGIATAN}

\section{Lokasi Dan Partisipan Kegiatan}

Kegiatan pengabdian kepada masyarakat dilaksanakan di Kelompok Peternak Tunas Mekar (KPTM), KSU Tandangsari, Kecamatan Tanjungsari, Kabupaten Sumedang, Provinsi Jawa Barat. Partisipan dari kegiatan pengabdian ini terdiri dari ketua dan pengurus KSU Tandangsari, ketua dan pengurus serta anggota kelompok Tunas Mekar. Kegiatan pelatihan dan pendampingan dilaksanakan selama enam bulan mulai dari Juni-Oktober 2020.

\section{Bahan dan Alat}

Kegiatan penyuluhan dilaksanakan dengan alat pengolah kata (Microsoft Office Word) dan alat pengolah angka (Micorsoft Office Excel) dalam komputer untuk keperluan penyusunan persuratan, kuesioner-kuesioner, dan leaflet yang dibagikan kepada para peserta penyuluhan. Oleh karena sedang berada dalam kondisi pandemi Covid-19, aplikasi komunikasi daring juga digunakan untuk melaksanakan komunikasi dengan para peternak peserta penyuluhan, yaitu menggunakan aplikasi Zoom Meeting. Selain itu, digunakan juga alat komunikasi berupa telepon pintar yang berisikan aplikasi-aplikasi, di antaranya aplikasi komunikasi, seperti Whatsapp dan email, juga aplikasi dokumentasi, seperti kamera. Sebagai langkah konkret bagi para peserta penyuluhan, dipersiapkan pula 75 bibit tanaman rumput mulato untuk dibagikan kepada para peserta penyuluhan untuk dibudidayakan.

\section{Metode Pelaksanaan Kegiatan}

Kegiatan penyuluhan dan pendampingan melibatkan 22 orang sebagai perwakilan anggota KPTM. Rangkaian kegiatan pengabdian kepada masyarakat ini dilaksanakan dengan tahapan dan metode yang dijelaskan oleh Kusumo et al. (2020) dan Purba et al. (2020), seperti yang ditunjukkan pada Gambar 1. Metode yang digunakan adalah dalam bentuk kegiatan penyuluhan pertanian yang dilakukan melalui beberapa tahapan awal berupa penjajakan, tahap penyusunan dan eksplorasi solusi yang ditawarkan, tahap pelaksanaan kegiatan penyuluhan dan penyebaran bibit rumput mulato, kemudian dilakukan kegiatan pendampingan dan evaluasi.

\section{- Tahap penjajakan}

Kegiatan penyuluhan diawali dengan proses penjajakan melalui wawancara dan penyebaran kuesioner yang bertujuan untuk mengidentifikasi masalah yang ada di KPTM (bulan Juli 2020). Permasalahan yang ditemukan dibahas dalam bagian hasil dan pembahasan dalam artikel ini. Setelah masalah utama di KPTM telah teridentifikasi, maka kegiatan pengabdian kepada masyarakat dilanjutkan dengan perumusan solusi untuk menangani permasalahan tersebut.

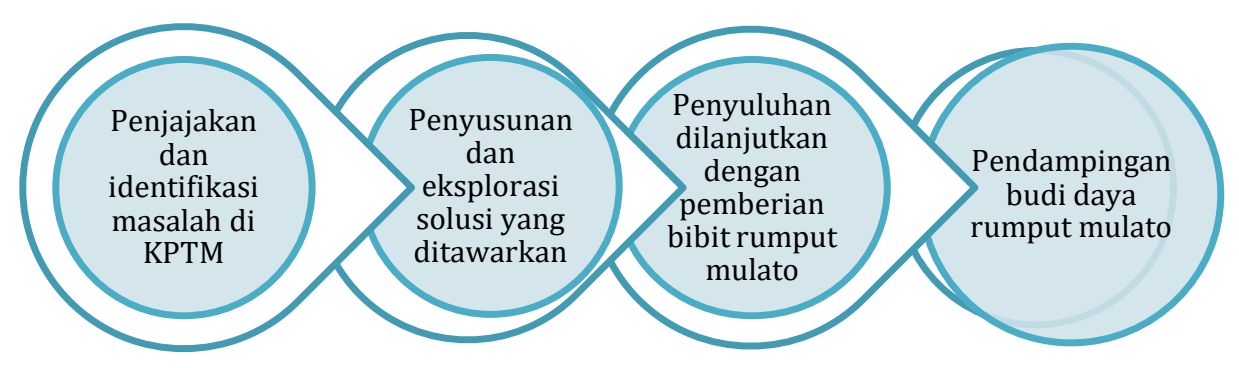

Gambar 1 Tahapan kegiatan pendampingan Kelompok Ternak Tunas Mekar. 
- Tahap penyusunan dan eksplorasi solusi yang ditawarkan

Tahap penyusunan dan eksplorasi solusi dilaksanakan berdasarakan masalah yang telah teridentifikasi dari tahap penjajakan. Tahap ini dilaksanakan dengan cara diskusi internal tim pelaksana pengabdian kepada masyarakat (PKM). Berdasarkan hasil diskusi, disetujui bahwa untuk menyediakan solusi atas permasalahan di KPTM, maka dilakukan penyusunan leaflet yang memuat informasi tinjauan pustaka dan percobaan mengenai keunggulan rumput mulato dan cara budidayanya. Tim pelaksana pengabdian kepada masyarakat (PKM) telah mencoba untuk memproduksi rumput mulato mulai dari penyemaian benih hingga proses pemanenan rumput, beserta pengukuran parameter-parameter produksinya, seperti teknis penyemaian, frekuensi penyiraman, spesifikasi media tanam, spesifikasi pupuk, intensitas penyinaran cahaya matahari, dan teknis pemanenan rumput. Seluruh informasi dari proses percobaan penanaman rumput mulato tersebut dituangkan ke dalam leaflet materi budi daya rumput mulato sehingga diharapkan dapat menyediakan informasi yang empiris dan komprehensif (Gambar 2).

\section{- Tahap penyuluhan}

Pada tahap berikutnya, dilaksanakan penyuluhan di KSU Tandangsari secara daring menggunakan Platform zoom meeting. Tahap

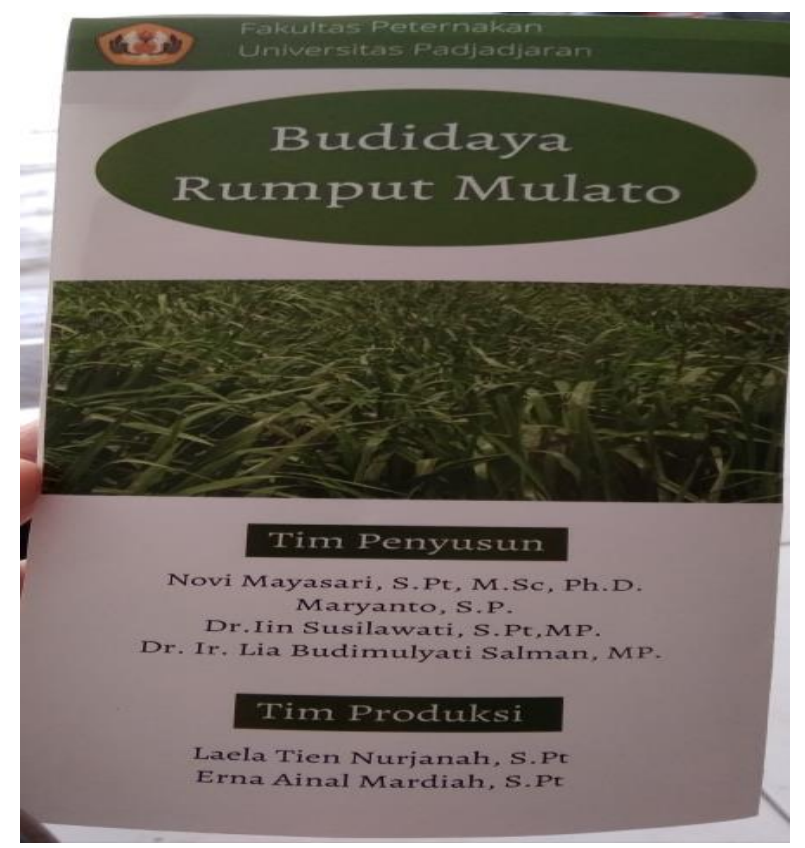

Gambar 2 Media penyuluhan berupa leaflet yang berisikan materi teknis penanaman dan budidaya rumput mulato. penyuluhan dilakukan dengan memberikan materi penyuluhan dari ahli hijauan dan tim ahli yang telah berpengalaman mengkaji produksi dan nutrien sapi perah. Selain materi penyuluhan berupa slide power point, juga diberikan leaflet budi daya rumput mulato sebagai sumber materi penyuluhan. Pada kegiatan penyuluhan disampaikan potensi penanaman rumput mulato di lahan milik peternak di Tunas Mekar. Kegiatan diskusi berlangsung cukup aktif, banyak peternak bertanya terkait cara penanaman, cara pemanenan hingga pemberiannya pada ternak. Pada akhir pemberian materi dilakukan sesi diskusi dengan memberikan pertanyaan langsung kepada peternak terkait materi yang disampaikan untuk memastikan bahwa mitra paham terhadap materi penyuluhan.

Tahap pengabdian ini kemudian dilanjutkan dengan pemberian bibit rumput mulato. Pemberian bibit diberikan kepada perwakilan anggota KPTM dan pengurus KSU Tandangsari ini merupakan bentuk nyata proses pengenalan rumput mulato terhadap KPTM, untuk ditanam dan dikembangbiakkan di lingkungan KPTM dan KSU Tandangsari.

\section{- Tahap pendampingan dan evaluasi}

Tahap penyuluhan dilanjutkan dengan tahap pendampingan dengan menggunakan fasilitas daring yaitu Whatsapp group dan Zoom meeting sebagai efisiensi komunikasi dan meminimalisasi kontak langsung karena sedang berada dalam situasi pandemi Covid-19. Pada tahap pendampingan, para anggota KPTM bebas berkonsultasi mengenai proses penanaman dan pemeliharaan rumput mulato di dalam whatsapp group jika terdapat permasalahan atau kendala di lapangan. Proses pendampingan ini terus berlangsung hingga para anggota KPTM dapat melakukan panen rumput mulato. Evaluasi kegiatan dilakukan dengan cara membandingkan tingkat wawasan dari para anggota peternak sebelum dan setelah dilakukan penyuluhan melalui diskusi. pre-test dan post-test dilakukan untuk mengukur pemahaman peserta sebelum dan setelah materi disampaikan. Pengisian pre-test, post-test, dan evaluasi dilakukan melalui laman Google form. Hasil yang diperoleh kemudian diolah dan disajikan dalam bentuk tabel. Pada tahap ini juga diperoleh data mengenai kepuasan program penyuluhan yang telah dilaksanakan dengan menggunakan survei kepuasan para peserta. Survei dilaksanakan dengan membagikan kuesioner secara daring (Google form) kepada para peserta untuk mengetahui sejauh 
mana kepuasan para peserta terhadap kegiatan penyuluhan yang telah dilaksanakan. Kuesioner yang telah dibuat memuat 5 pertanyaan sederhana yang menyangkut aspek kepuasan dan pemahaman mengenai materi keunggulan rumput mulato beserta cara budidayanya.

\section{HASIL DAN PEMBAHASAN}

\section{Tahap Penjajakan}

Kegiatan awal pengabdian dilakukan sebagai penjajakan yang dilakukan melalui komunikasi dengan pengurus KSU dan anggota kelompok peternak yang dipilih pengurus berdasarkan permasalahan yang dihadapi. Tahapan penjajakan dilakukan untuk mengetahui kondisi, situasi, dan profil dari kelompok peternak objek penyuluhan (dalam hal ini, KPTM). Wawancara dilakukan dengan menggunakan kuesioner pada beberapa peternak dan pengurus KSU Tandangsari. Keseluruhan responden adalah sebanyak 10 orang.

Berdasarkan hasil penjajakan, beberapa permasalahan yang telah teridentifikasi di lapangan di antaranya adalah terkait rendahnya produksi susu, kualitas susu, kesehatan sapi, dan masalah limbah peternakan yang belum dapat teratasi dengan baik. Para peternak dan koperasi sangat menyoroti masalah terkait rendahnya produksi susu akibat dari belum tercukupinya kebutuhan pakan terutama hijauan. Rendahnya kualitas dan kontinuitas hijauan utama (rumput) untuk ternak sapi perah yang dimiliki oleh para anggota peternak terjadi pada saat musim kemarau. Masalah lain yang ditemui adalah rendahnya kualitas dan kuantitas susu dari sapi perah yang dimiliki oleh para peternak yang sangat terkait dengan kualitas hijauan itu sendiri. Selanjutnya, ditemukan juga masalah rendahnya tingkat kesehatan sapi perah sehingga produktivitasnya tidak mencapai tingkat yang optimal. Oleh karenanya, diketahui bahwa kelompok Tunas Mekar merupakan salah satu kelompok peternak KSU Tandangsari yang memiliki produksi susu terendah dan memiliki permasalahan terkait kesehatan ternak. Berdasarkan beberapa masalah tersebut, diperoleh akar masalah, yaitu terdapatnya kekurangan asupan nutrien yang diberikan kepada sapi perah, oleh karenanya fokus dari kegiatan ini adalah menyediakan solusi bagi akar masalah tersebut.

KPTM beranggotakan 43 orang peternak dengan (69\% pria, 31\% wanita; Gambar 3), yang seluruhnya tinggal di Desa Cipacing, Kecamatan Tanjungsari, Kabupaten Sumedang. Total populasi sapi perah strain Friesian Holstein (FH) yang dimiliki oleh seluruh anggota peternak di KPTM berjumlah 267 ekor (pada September 2020). Jika dirata-ratakan, setiap anggota peternak di KPTM memiliki 6 ekor sapi dengan sebaran proporsinya digambarkan pada Gambar 4. Dari keseluruhan populasi, sapi yang berada dalam masa laktasi (ke I-VI) berjumlah 111 ekor, dengan rata-rata produksi susu harian sebanyak $12 \mathrm{~kg} /$ ekor/hari.

Lebih lanjut, diketahui bahwa para anggota peternak KPTM menggunakan hijauan berupa rumput lapangan dan jerami padi yang memiliki kualitas rendah dan ketersediaannya yang tidak kontinu. Guna mengimbangi kekurangan nutrien dari hijauan dan konsentrat, para anggota peternak KPTM memberikan bahan pakan lain seperti ampas tahu dan sisa bubuk kue kepada sapi-sapi yang dimilikinya. Meskipun baik, hal ini belum berdampak secara optimal pada proses produksi susu sapi perah, tercermin dari belum meningkatnya rata-rata produksi susu harian pada sapi perah yang dimiliki oleh para anggota peternak KPTM. Para anggota peternak KPTM juga telah mencoba untuk mengawetkan hijauan dengan cara pembuatan silase, namun dirasa

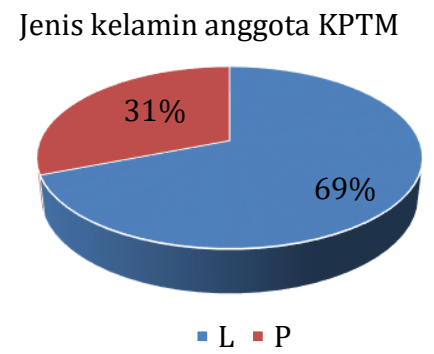

Gambar 3 Proporsi anggota kelompok peternak Tunas Mekar berdasarkan jenis kelamin.

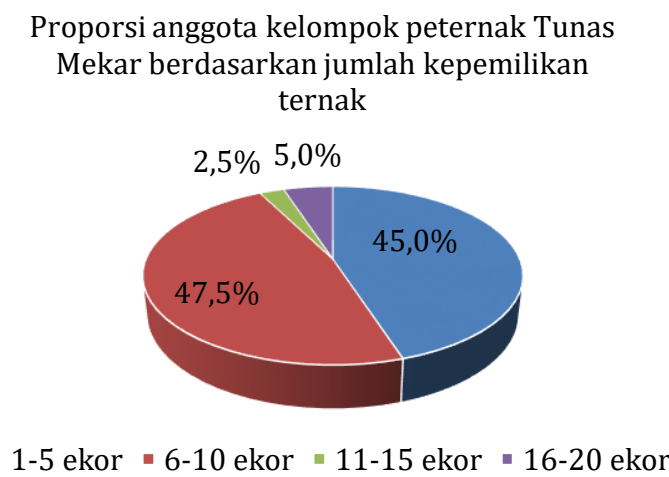

Gambar 4 Proporsi anggota kelompok peternak Tunas Mekar berdasarkan jumlah kepemilikan ternak. 
tidak optimal dikarenakan ketersediaan bahan baku hijauan yang tidak berkelanjutan.

\section{Tahap Penyusunan dan Eksplorasi Solusi yang Ditawarkan}

Setelah masalah berhasil teridentifikasi, kemudian dilaksanakan perancangan solusi dan koordinasi dengan pihak KPTM mengenai penjadwalan penyuluhan. Penyuluhan tidak sepenuhnya dilakukan secara tatap muka dikarenakan kondisi pandemi Covid-19 yang membatasi kegiatan-kegiatan yang melibatkan massa yang besar. Hasil diskusi dengan pengurus KSU, maka diputuskan untuk melakukan kegiatan penyuluhan dan pengabdian secara luring dengan pembatasan kehadiran peserta penyuluhan. Salah satu upaya penyuluhan untuk menyelesaikan permasalahan peternak KPTM, maka dibuatlah modul, materi dan leaflet yang berisi panduan untuk proses budidaya rumput mulato.

Penyusunan leaflet tersebut didasarkan pada hasil proses percobaan penyemaian benih mulato yang dilakukan oleh tim PKM. Berdasarkan proses percobaan, didapat hasil bahwa benih mulato dapat berkembang dengan baik jika dilakukan perendaman dengan air terlebih dahulu semala kurang lebih 24 jam. Kemudian, benih disemai di media tanah yang subur tetapi tidak terlalu basah untuk menghindari adanya kontaminasi jamur. Kemudian, benih sudah mulai mengeluarkan daun pada 3-4 hari setelah penyemaian, dan dapat dipindahkan ke dalam media yang lebih besar di dalam polybag setelah berumur 7-14 hari setelah penyemaian.

\section{Tahap Penyuluhan dan Penyebaran Bibit}

Kegiatan utama dari pengabdian ini adalah kegiatan penyuluhan yang disertai pelatihan singkat dilaksanakan dengan cara ceramah mengenai penyampaian latar belakang dan permasalahan yang ingin diselesaikan. Pemberian materi dilakukan oleh tiga orang dosen yang memiliki kompetensi dalam menawarkan solusi terkait produksi dan nutrien termasuk penyediaan hijauan pakan ternak. Penyuluhan diawali dengan diskusi (pre-test) mengenai permasalahan utama yang didapat saat penjajakan serta diskusi langsung dengan peternak, yaitu mengenai rendahnya kualitas hijauan di KPTM dengan ketersediaannya yang tidak berkelanjutan dan tidak stabil. Solusi yang diajukan untuk menyelesaikan masalah tersebut adalah dengan memperkenalkan potensi rumput mulato hybrid II yang memiliki kualitas yang baik serta potensi produksi yang tinggi walaupun ditanam pada ketinggian yang rendah dan kualitas tanah yang terbatas. Kondisi tanah dan iklim di Kecamatan Tanjungsari cukup beragam karena kontur tanah yang juga tidak sama pada setiap wilayah. Namun berdasarkan kajian yang dilakukan terkait potensi penanaman rumput mulato di wilayah KPTM, dirasa cukup berpotensi. Kegiatan penyuluhan dilanjutkan dengan pertemuan tatap muka dengan jumlah peserta yang dibatasi. Pada kegiatan tatap muka ini kemudian diserahkan sejumlah bibit rumput mulato untuk dimulai dibudidayakan di lingkungan KPTM dan KSU Tandangsari.

Acara penyuluhan dihadiri oleh ketua dan pengurus KSU serta perwakilan anggota KPTM dengan antusiasme yang tinggi. Oleh karena terdapat pembatasan peserta yang hadir, maka pada kegatan penyuluhan ini dihadiri oleh 5 orang sebagai perwakilan dari kelompok peternak. Namun demikian, proses penyuluhan dilanjutkan dengan tahap pendampingan secara daring (menggunakan Whatsapp dan Zoom meeting) yang mengikutsertakan lebih banyak anggota kelompok peternak. Adapun materi yang disampaikan dalam sesi ceramah adalah mengenai teknis budi daya rumput mulato yang didukung dengan rangkuman materi berupa leaflet yang dibagikan kepada seluruh hadirin (Gambar 2). Materi mengenai budi daya rumput mulato merupakan hasil dari percobaan secara langsung produksi rumput mulato yang telah dilaksanakan sebelumnya. Secara garis besar, leaflet budi daya rumput mulato tersebut memuat a) Proses pemilihan dan persiapan benih; b) Proses persiapan dan spesifikasi media tanam beserta pupuknya; c) Proses perawatan rumput, frekuensi penyiraman, dan intensitas cahaya matahari yang dibutuhkan; dan d) Fasefase produksi dan panen.

Seperti yang telah dilaporkan oleh Suardin et al. (2014), rumput mulato memiliki kemampuan hidup pada musim kemarau yang baik, mudah dikembangbiakkan melalui anakan, dan palatabilitas oleh ternak ruminansia yang cukup tinggi. Selain itu, Djaya (2014) melaporkan bahwa rumput mulato superior dalam kualitas dan produktivitas, tahan terhadap tekanan penggembalaan, kemampuan pertumbuhan kembali (regrowth) yang baik, dapat digunakan sebagai rumput potong atau rumput gembala, palatabilitasnya sangat baik. Lebih jauh lagi, Brandan et al. (2017) melaporkan bahwa tanaman rumput mulato dapat juga difungsikan sebagai tanaman pelindung (cover crop) bagi 
tanaman lain, dengan keunggulan untuk memulihkan sifat biokimia tanah sehingga meningkatkan kesuburan tanah. Ketika dibandingkan dengan rumput lai (semisal rumput Bahia), mulato memiliki kecernaan bahan organik yang lebih baik (Inyang et al. 2010). Keunggulan-keunggulan tersebutlah yang membuat rumput mulato menjadi menarik untuk dikembangbiakkan lebih intensif.

Acara penyuluhan yang diselenggarakan memantik banyak diskusi dari para anggota peternak KPTM. Setelah pemaparan materi selesai dilaksanakan, acara kemudian dilanjutkan dengan sesi diskusi kelompok terarah (Focus Group Discussion/FGD) seperti yang telah dipaparkan oleh (Ruhiyat et al. 2020). Anggota peternak KPTM sangat antusias mengikuti sesi FGD, sehingga banyak bertanya mengenai teknis penanaman dan budi daya rumput mulato. Anggota peternak juga merasa yakin akan keunggulan produksi yang dimiliki oleh rumput mulato. Pada akhir acara penyuluhan, terdapat sesi penyerahan bibit rumput mulato siap tanam yang diwajibkan untuk ditanam dan dibudidayakan oleh para anggota peternak KPTM (Gambar 5). Proses penanaman dan budi daya rumput mulato ini dipantau dan didampingi dalam tahap pendampingan.

\section{Tahap Evaluasi dan Pendampingan}

Tahap pendampingan berlangsung setelah berakhirnya acara penyuluhan dengan menggunakan whatsapp group bersama para anggota KPTM (Gambar 6). Tahap ini bertujuan untuk menjamin seluruh bibit yang diserahkan kepada perwakilan anggota KPTM ditanam dan dibudidayakan. Proses konsultasi budi daya mulato melalui whatsapp group ini cukup efektif dan efisien. Para anggota KPTM tidak sungkan untuk bertanya jika menemui kendala dan permasalahan di lapangan. Kegiatan pendampingan ini merupakan salah satu upaya pengukuran keberhasilan dari kegiatan penyuluhan yang dilakukan sebelumnya.

Berdasarkan hasil pemantauan melalui Whatsapp group tersebut, pada anggota KPTM berhasil membudidayakan bibit rumput mulato yang disediakan melalui media polybag terlebih dahulu (Gambar 7). Bahkan, beberapa anggota menyebarluaskan lagi anakan rumput mulato tersebut dan ditanam di tempat lain oleh kenalannya. Penyebarluasan informasi ini dirasa telah mencapai tujuan karena anggota KPTM dapat membudidayakan rumput mulato. Terdapat 22 orang anggota peternak yang ber-

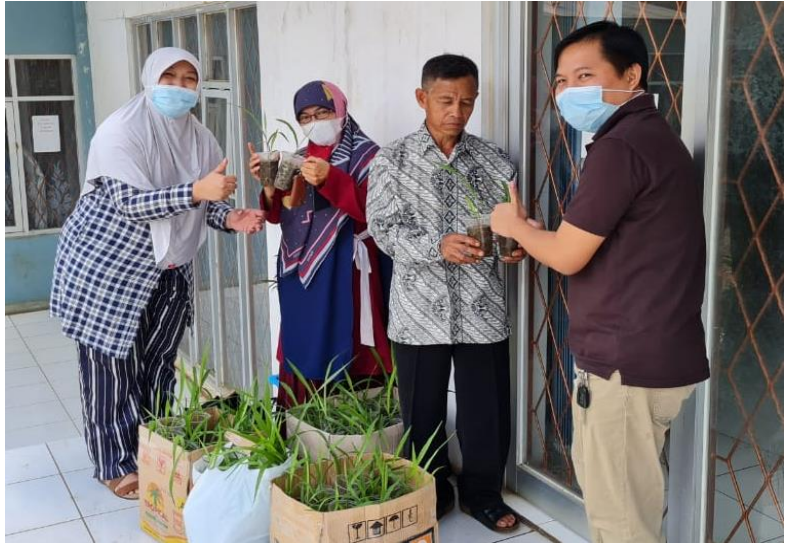

Gambar 5 Proses serah terima bibit mulato pada akhir acara penyuluhan.

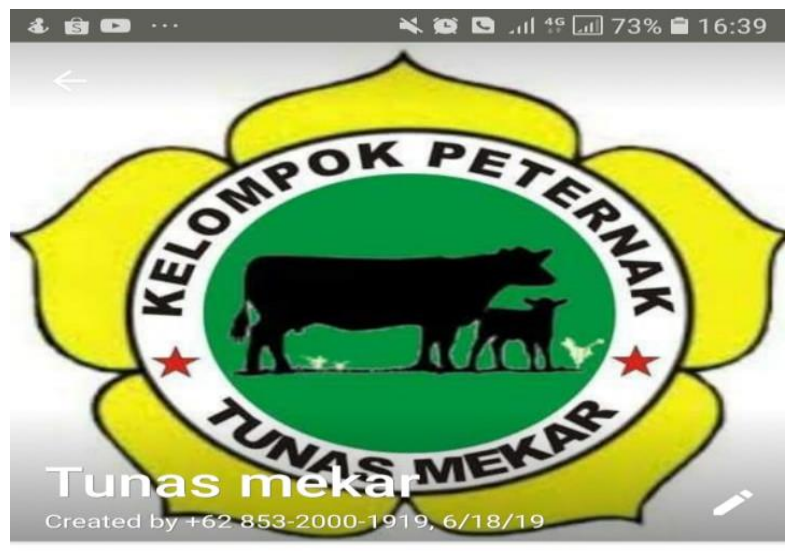

Add group description

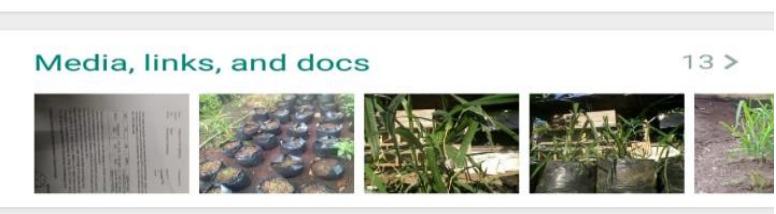

Mute notifications

Gambar 6 Whatsapp group sebagai media komunikasi proses pendampingan budidaya rumput mulato.

gabung ke dalam Whatsapp group ini, dan seluruhnya aktif berdiskusi jika memiliki pertanyaan. Peternak melaporkan pertumbuhan mulato dalam satu bulan dengan mengirimkan foto-foto anakan dari bibit rumput mulato yang diberikan. Dalam waktu satu bulan anakan yang dihasilkan sebanyak 4-6 anakan. Selain itu, seluruh bibit yang diberikan kepada peternak berhasil tumbuh dan dibudidayakan seluruhnya $(100 \%)$ oleh para peternak. Proses pendampingan terus berlangsung untuk menjamin produksi rumput mulato dapat ditingkatkan menjadi lebih tinggi lagi, agar ketersediaannya dapat terjamin.

Hasil evaluasi dan monitoring terhadap pelaksanaan kegiatan menunjukkan adanya 
peningkatan pengetahuan anggota kelompok dalam menghasilkan jumlah anakan dari bibit mulato yang diberikan. Hasil angket/kuesioner menunjukkan bahwa sebanyak 20 orang anggota $(90,9 \%)$ peserta memahami dengan baik seluruh materi pelatihan, sedangkan sebanyak 2 orang $(9,1 \%)$ cukup memahami seluruh materi yang diberikan (Tabel 2). Tingkat kepuasan peserta pengabdian menunjukkan bahwa sebanyak 16 orang (73\%) merasa sangat puas dan sebanyak 6 orang $(27 \%)$ merasa puas. Peserta merasa puas karena seluruh materi pelatihan yang diberikan mudah dipahami dan disertai dengan praktik langsung untuk membudidayakan rumput mulato secara mandiri sehingga meningkatkan pemahaman anggota peternak. Tingkat keberhasilan kegiatan pengabdian ini ditentukan oleh faktor pendukung dan juga faktor penghambat yang menjadi kendala bagi tim penyuluh dan juga anggota kelompok peternak.

\section{Faktor Pendukung}

Kegiatan pengabdian ini direncanakan dan dirancang sesuai kesepakatan ketua dan pengurus KSU Tandangsari, para anggota peternak Tunas Mekar dan Tim PKM UNPAD, sehingga partisipasi petani peternak dan juga para

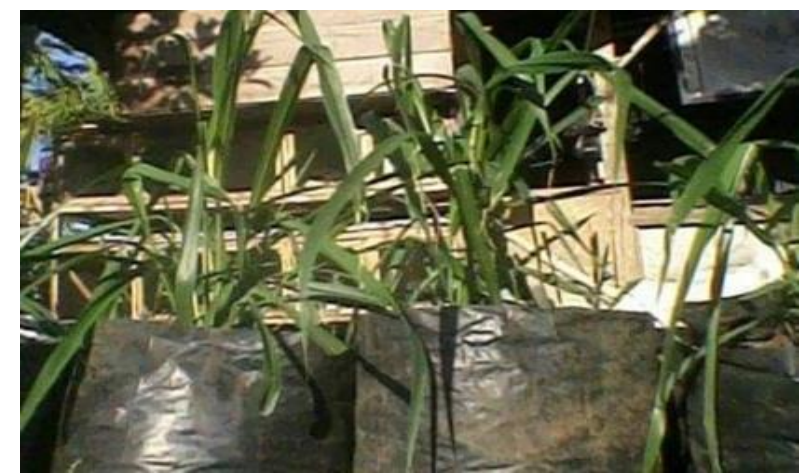

a pengurus di KSU sangat baik. Kegiatan ini merupakan kelanjutan dari kegiatan pengabdian yang dilakukan di kelompok Tunas Mekar dari tahun 2018 hingga sekarang. Kegiatan ini mendapat dukungan penuh dari Ketua KSU Tandangsari, petani, peternak, dan masyarakat.

\section{Faktor Penghambat}

Penyediaan baik benih/biji ataupun bibit rumput Mulato hybrid II masih terbatas. Perlu pen-dampingan secara intensif bagi peternak, terutama bagi petani-peternak yang tidak memiliki lahan cukup untuk menanam rumput secara mandiri.

\section{SIMPULAN}

Kegiatan pengabdian kepada masyarakat mengenai potensi rumput mulato sebagai hijauan untuk sapi perah berhasil dilaksanakan. Dengan antusiasme peternak peserta penyuluhan, kegiatan penyuluhan dapat meningkatkan wawasan peternak peserta penyuluhan, tercermin dari berhasilnya peternak untuk menanam dan membudidayakan tanaman rumput mulato. Para anggota KPTM terus didampingi dengan tujuan

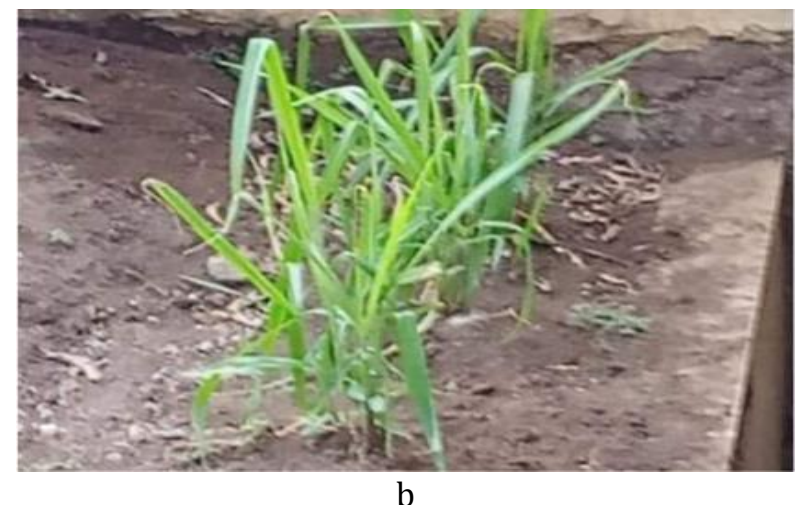

Gambar 7 a) Rumput pulato yang berhasil ditanam oleh para peternak anggota kelompok peternak Tunas Mekar pada media tanam polybag dan b) Perbanyakan anakan tanaman rumput Mulato.

Tabel 2 Hasil evaluasi pemahaman peserta melalui rangkaian pre-test dan post-test.

\begin{tabular}{|c|c|c|}
\hline \multirow[b]{2}{*}{ Indikator } & Baseline & Pencapaian \\
\hline & $\begin{array}{l}\text { (Pre-test) sebelum } \\
\text { kegiatan penyuluhan }\end{array}$ & $\begin{array}{c}(\text { Post-Test }) \\
\text { setelah kegiatan penyuluhan }\end{array}$ \\
\hline $\begin{array}{l}\text { Pengetahuan tentang jenis, morphologi } \\
\text { dan karater pertumbuhan rumput } \\
\text { mulato }\end{array}$ & Sedikit tahu (10\% dari peserta) & Meningkat $90 \%$ dari peserta \\
\hline $\begin{array}{l}\text { Pengetahuan peternak mengenai potensi } \\
\text { rumput mulato sebagai sumber hijauan } \\
\text { ruminansia }\end{array}$ & Sedikit tahu (10\% dari peserta) & Meningkat $90 \%$ dari peserta \\
\hline $\begin{array}{l}\text { Pengetahuan peternak mengenai } \\
\text { budidaya rumput mulato }\end{array}$ & Sedikit tahu (10\% dari peserta) & Meningkat $90 \%$ dari peserta \\
\hline
\end{tabular}


untuk meningkatkan lagi tingkat produksi rumput mulato sehingga keberlanjutannya dapat terjamin. Di dalam tahap pendampingan, para peserta dapat melakukan diskusi secara bebas terkait permasalahan yang mungkin timbul di lapangan ketika membudidayakan rumput mulato. Berdasarkan pelaporan dari grup Whatsapp pada tahap pendampingan, seluruh bibit yang diberikan kepada para peternak berhasil tumbuh (100\%), bahkan, para peternak berhasil membuat secara rata-rata 4-6 anakan dari setiap bibit tanaman yang diberikan. Keberlanjutan program mengenai penyebar luasan potensi dan budidaya rumput mulato perlu terus dilaksanakan, khususnya untuk meningkatkan kualitas dan kualitas benih/bibit rumput mulato sehingga semakin banyak peternak dapat menggunakan mulato sebagai alternatif hijauan untuk ternaknya.

\section{UCAPAN TERIMA KASIH}

Tim penulis mengucapkan terima kasih kepada Universitas Padjadjaran sehingga kegiatan pengabdian kepada masyarakat ini dapat terlaksana melalui DIPA BLU Universitas Padjadjaran Nomor: 1397/UN6.3.1/PM/2020 Tanggal 9 April 2020. Tim penulis juga mengucapkan terima kasih kepada Laela Tien Nurjanah, Erna Ainal Mardiah, Lia Rachmawati, dan Ferdy atas segala bantuan untuk menyelenggarakan kegiatan ini.

\section{DAFTAR PUSTAKA}

Brandan CP, Chavarría D, Huidobro J, Meriles JM, Brandan CP, Vargas Gil S. 2017. Influence of a tropical grass (Brachiaria brizantha cv. Mulato) as cover crop on soil biochemical properties in a degraded agricultural soil. European Journal of Soil Biology 83:84-90. https://doi.org/10.1016/j.ejsobi.2017.10.00 9

Djaya MS. 2014. Kecernaan in vitro dan serat kasar rumput mulato dan kalopo pada tingkat naungan dan sistem pertanaman yang berbeda. Polhasains: jurnal sains dan terapan Politeknik Hasnur. 3(01): 34-41.

Inyang U, Vendramini JMB, Sollenberger LE, Sellers B, Adesogan A, Paiva L, Lunpha A. 2010. Forage Species and Stocking Rate Effects on Animal Performance and Herbage Responses of 'Mulato' and Bahiagrass Pastures. Crop
Science 50(3):1079-1085. https://doi.org/ 10.2135/cropsci2009.05.0267

Kusumo RAB, Sukayat Y, Heryanto MA, Wiyono SN. 2020. Budidaya sayuran dengan teknik vertikultur untuk meningkatkan ketahanan pangan rumah tangga di perkotaan. Dharmakarya 9(2):89-92. https://doi.org/ 10.24198/dharmakarya.v9i2.23470

Liu S, Zhang R, Kang R, Meng J, Ao C. 2016. Milk fatty acids profiles and milk production from dairy cows fed different forage quality diets. Animal Nutrition. 2(4): 329-333. https:// doi.org/10.1016/j.aninu.2016.08.008

Makin M. 2012. Performa Sifat-Sifat Produksi Susu dan Reproduksi Sapi Perah Fries Holland Di Jawa Barat. Jurnal Ilmu Ternak Universitas Padjadjaran. 12(2): 39-44.

Maranatha G, Manu AE, Sobang YUL, Samba FD, Pelokilla MR. 2019. The evaluation of nutritive value and in vitro digestibility of Mulato grass (Brachiaria hybrid cv. Mulato) grown under mixed culture system with legume and horticulture plants on dry land. In: IOP Conference Series: Earth and Environmental Science 387:12032. https://doi.org/ 10.1088/1755-1315/387/1/012032

Mutimura M, Ebong C, Rao IM, Nsahlai I V. 2017. Effect of cutting time on agronomic and nutritional characteristics of nine commercial cultivars of Brachiaria grass compared with Napier grass during establishment under semi-arid conditions in Rwanda. African journal of agricultural research. 12(35): 26922703. https://doi.org/10.5897/AJAR2017. 12474

Purba NP, Faizal I, Setiwati D, Mulyani PG. 2020. Teknologi dan pendampingan monitoring perairan untuk budidaya di desa Babakan, kabupaten Pangandaran. Dharmakarya 9(1):12-15. https://doi.org/10.24198/ dharmakarya.v9i1.21354

Ruhiyat R, Indrawati D, Indrawati E, Siami L. 2020. Pemberdayaan Masyarakat Melalui Sistem Pertanian Terpadu di Desa Cibodas Kecamatan Pasirjambu, Kabupaten Bandung. Agrokreatif: Jurnal Ilmiah Pengabdian kepada Masyarakat 6(2):97-104. https://doi.org/10. 29244/agrokreatif.6.2.97-105

Suardin S, Sandiah N, Aka R. 2014. Kecernaan bahan kering dan bahan organik campuran rumput mulato (brachiaria hybrid. cv. mulato) 
dengan jenis legum berbeda menggunakan cairan rumen sapi. Jurnal Ilmu dan Teknologi Peternakan Tropis 1(1):16-22. https://doi. org/10.33772/jitro.v1i1.357

Wanapat M, Cherdthong A, Phesatcha K, Kang S. 2015. Dietary sources and their effects on animal production and environmental sustainability. Animal Nutrition. 1(3): 96-103. https://doi.org/10.1016/j.aninu.2015.07.004
Wang H, He Y, Li H, Wu F, Qiu Q, Niu W, Gao Z, Su H, Cao B. 2019. Rumen fermentation, intramuscular fat fatty acid profiles and related rumen bacterial populations of Holstein bulls fed diets with different energy levels. Applied Microbiology and Biotechnology. 103(12): 4931-4942. https:// doi.org/10.1007/s00253-019-09839-3. 